\title{
Government Education Spending and Education Outcome in Nigeria
}

\author{
Charles Uchenna Obi ${ }^{1}$, Sylvester Chukwunonso Ekesiobi ${ }^{2}$, Stephen Kelechi Dimnwobi ${ }^{1}$, \\ Emilia Mukosolu Mgbemena ${ }^{2}$ \\ ${ }^{1}$ Department of Economics, Nnamdi Azikiwe University, Awka, Nigeria \\ ${ }^{2}$ Department of Economics, Chukwuemeka Odumegwu Ojukwu University, Igbariam, Nigeria
}

Email address:

stephenkcdim@gmail.com (S. K. Dimnwobi)

\section{To cite this article:}

Charles Uchenna Obi, Sylvester Chukwunonso Ekesiobi, Stephen Kelechi Dimnwobi, Emilia Mukosolu Mgbemena. Government Education Spending and Education Outcome in Nigeria. International Journal of Economics, Finance and Management Sciences. Vol. 4, No. 4, 2016, pp. 223-234. doi: 10.11648/j.ijefm.20160404.18

Received: July 14, 2016; Accepted: July 25, 2016; Published: August 6, 2016

\begin{abstract}
Expenditure on education is regarded as investment in human capital because it helps in skill formation and thus raises the ability to work and produce more. Government education spending is of great importance to national development and plays a critical role in promoting growth and knowledge deepening. This paper examines government education spending and education outcome in Nigeria from 1970 - 2013. Employing Augmented Dickey Fuller (ADF) unit root test and Ordinary Least Square (OLS) technique, the study revealed that public education spending has a positive and significant effect on education outcome in Nigeria. Public health expenditure and urban population growth were also found to have positive effects on education outcome but are non significant in determining education outcome. The study recommends among other things, that government should spend more on education which needs to be targeted for the desired effects to be realized. Again government should monitor spending given the history of corruption and embezzlement of public funds in Nigeria.
\end{abstract}

Keywords: Government Spending, Education Outcome, Economic Development

\section{Background to the Study}

The increasing importance of education in any economy cannot be over emphasized. Investment in education and training is imperative to propel any economy to higher level of productivity and accelerate the rate of economic growth [48]. Education increases the number of knowledgeable workers by improving their skills and preparing them adequately for new challenges [48]. More so, education enhances occupational mobility, reduces the level of unemployment in the economy, increases the earning capacity and productivity of the country's work force, improves access to health information which will increase life expectancy and, at the same time manage the fertility rate. Therefore, education is capable of enhancing the efficient production of goods and services by ensuring thorough screening whereby the best people are selected and made available for the world of research [50].

Public education expenditures have been recognized as a key aspect of fiscal outlays in most developing countries of the world. This is mainly because education and human capital have been found to have a positive and significant effect on economic growth [67], [2], [3]. Education reduces fertility rates [38], improves health, and enhances social and political participation [27]. There is increasing empirical evidence that education matters, not only for the personal development, health status, social inclusion and labour market prospects of individual learners, but also for the broader economic performance of countries [45], [46]. As the world has entered the age of the knowledge economy, education and human capital generally play a critical role in driving economic growth in both the world's most advanced economies and the emerging economies that are currently experiencing profound transformations and periods of rapid growth and development. According to [60], education has both intrinsic and instrumental values. It is desirable not only for the individual but also for the society as a whole. Education as private good benefits directly those who receive it, which in turn affects the individual's future income stream. At the aggregate level, a 
better educated workforce is thought to increase the stock of human capital in the economy and increase its productivity. Considering the externalities prevalent in education, it is widely accepted that the state has a key role to play in ensuring equitable distribution of educational opportunities to the entire population. This is particularly crucial in developing countries that suffer from high levels of poverty, inequality and market imperfections. Public intervention in education can lead to improvement in the future stream of individuals, enabling equitable distribution of wealth and help reduce poverty [40].

Furthermore, the justification of public spending on social goods, particularly education, is based on the classical literature on public goods, where it is argued that social goods provide a rationale for the allocative function of budget policy [11]. It is argued that the public sector performs certain functions because some goods cannot be provided efficiently through the market system owing to apparent market failures or associated inefficiencies. Market failure occurs because the benefits created by social goods are not limited to one particular consumer who purchases the goods, as is the case with private goods. The non-rival or non-excludability nature of public goods has important implication for consumer behaviour and on the provision of both private and social goods [41]. Although the market mechanism is structured for the provision of private goods, the exclusivity of the title accorded purchasers of private goods is lacking in social goods. It would be inefficient therefore to exclude any consumer from partaking in the benefits of a social good since such consumption does not reduce or limit the benefits accorded to others [52].

Although the relevance of government expenditure to education access and equity is well documented, there have been concerns about the allocative efficiency of such government spending. How much is enough for optimal education outcome in developing countries? Should government spending on education continue to rise, and does such increase guarantee commensurate returns in education outcome? Indeed, the extent to which the level of school funding is important for the achievement of education outcomes has been a long-standing concern in both the developed and developing countries. Many analysts argue that the injection of additional financial resources into schools, by itself, has limited impact on realizing education goals [25], [26]. On the other hand, some scholars assert that money does indeed matter in the attainment of education objectives [18], [19], [29]. These contradictory views are of crucial policy concerns to developing countries who over time have advocated higher education attainment as the path out of underdevelopment, and higher government spending the surest way of substantially increasing education attainment. An analysis that reassess this much held views would undoubtedly realign policy perspectives in Nigeria on the right path, as well as modify the views of policy makers on what works and what does not work in different climes. Figure 1 below shows youth and adult literacy levels in Sub Saharan Africa alongside share of public spending on education over time. It is noticeable that both adult and youth literacy rates increased over time, and public spending on education increased as well. This although is a welcome development does not suggest that education spending in SSA is being efficiently allocated, especially in the light of the fact that SSA is a region with profound public revenue limitations due to mainly a low tax base.

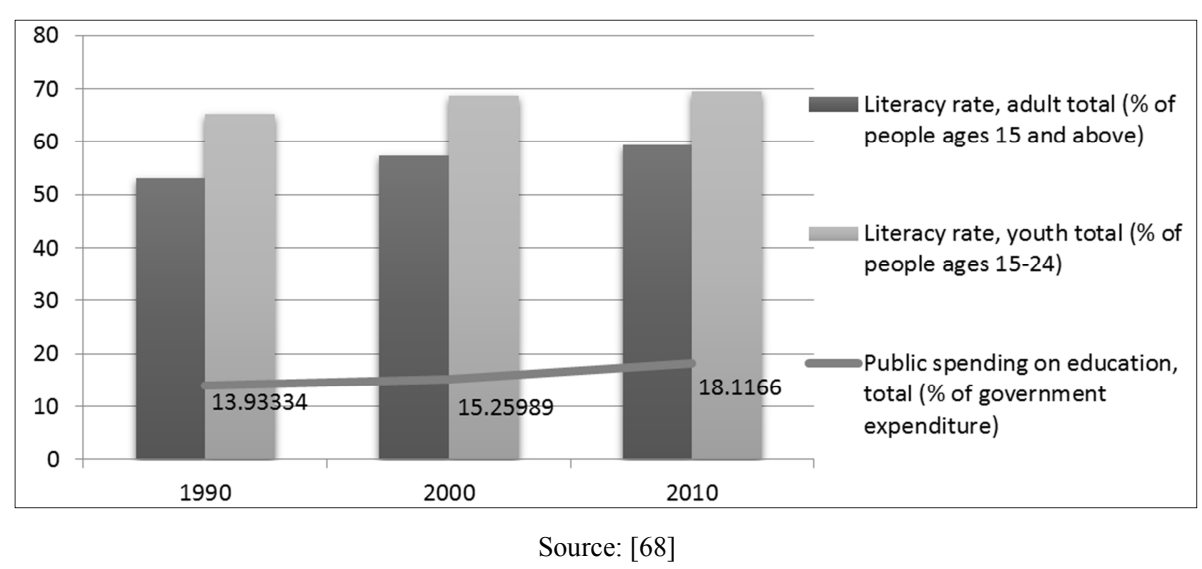

Figure 1. Literacy Levels and Public Education Expenditure in SSA over time.

Moreover, that education spending and literacy levels in SSA have tended to move up together over time (figure 1 above) does not in any way suggest of causation. Similar findings were reported for Nigeria in [65], as the study shows that education spending in the country has tended to rise in recent years, while literacy level has not worsened. This notwithstanding, it has been shown that education spending in Nigeria has been inadequate, as it has underperformed that of other developing nations (like Ghana who spends $20 \%$ of its expenditure on education, Bostwana who spent a historical average of $21 \%$, Kenya who spent $20 \%$ and Uganda who spent $15 \%$, while Nigeria spent only 3\%, [65]. Aside this, Nigeria has also fallen short of the United Nations suggested spending of $26 \%$ of GDP for developing nations.

The central focus of this study is to assess the impact of education spending on education outcome in Nigeria. In a bid to achieve this, this paper will be divided across a fivesection arrangement. While the first section introduces the 
paper, section two looks at the review of related literature. Section three discusses the methods and procedures employed for the study. While section four looks at the data analysis and presentations of findings, the final section articulates the recommendations and conclusion.

\section{Review of Related Literature}

\subsection{Conceptual Discussions}

Government spending or public expenditure is the outflow of resources from government to the various sectors of the economy. It is often divided into capital and recurrent expenditures [8]. Public expenditure is a more effective way of producing services. Capital expenditure has been defined as payment for non-financial assets used in the production for more than one year, while recurrent expenditures are payments for non-repayable transactions within a year, [8]. It has a crucial role in investment on infrastructure [17]. As observed by [32] government expenditure is influenced by rapid population growth, demographic transitions, taste of the people in a country, increase in technological requirements for industrialization, increase in urbanization, increase in inflation over time, balance in productivity growth between public and private sector, and the need to address natural disaster [17].

Education outcomes simply mean the goals for learning and development upon which higher education general education programs are based [53]. In addition it can be seen as the knowledge, skills, attitudes, and values that college students will need to be successful in work, family, and community. Basically, they are what students should know, understand, and be able to do in order to be an educated person and to meet the demands that the future will place on them, the demands of the complex, diverse, and globally interdependent world of the 21st century [53]. It can also be seen as general education abilities, general education goals, general competencies, core abilities, core competencies, essential learning outcomes, learning goals, learning objectives, college wide outcomes, principles of undergraduate learning, and transferable skills of liberal learning etc [53].

\subsection{Theoretical Literature Review}

\subsubsection{Education Spending Overview}

Better educated persons are more likely to get employment and are less likely to lose their jobs, if they are gainfully employed. The labour participation rate increases with the level of education attained by individuals. Persons with the highest qualifications earn the highest incomes [49]. Analyses of the effects of education have often striven to attribute differences in personal incomes to workers' unequal endowment in human capital. Accordingly, the traditional theories of human capital [35], [5] explicitly posit that workers are remunerated on the basis of their marginal productivity and more educated workers logically earn higher wages because they are supposedly more productive.

In early growth models such as [62], long-term growth was made dependent on technological advancement, without any real analysis of its origin. However, the important role of education was still mentioned. Research on growth factors took a new dimension with the works of [56] and [33] who focused on new theories of endogenous growth. Through more rigorous analysis, they demonstrated that countries which made a greater effort in educating their citizens became richer than others who do not. This result was obtained either by establishing an analogy between human capital and physical capital, i.e., considering human capital as a factor whose accumulation raises the level of production, or by assuming that human capital directly affects the growth rate through technological advancements [24].

[42] stated that since education is essentially the capacity to understand new information and adapt one's behaviour accordingly, economies that have the greatest number of highly-skilled workers will more rapidly adopt and implement the most efficient technologies. According to them, it is the level of education that raises the economic growth rate by speeding up the assimilation of technological progress. Another mechanism was later identified by [57] who examined the relevance of research and development (R\&D) activities. The study established that accumulating a stock of knowledge makes it possible to increase efficiency in generating wealth through labour and capital. Raising the level of education, and consequently the number of highlyskilled workers who can participate in such accumulation of knowledge will increase the pace of discoveries and consequently multiply economic growth possibilities.

More formal theories have laid out explicitly the role of education-human capital-in the development of economies. In the following sections, some of these theories are outlined.

\subsubsection{Theoretical Issues}

i. Musgrave and Rostow theory of public expenditure

Musgrave and Rostow put forward a development model under the causes for growth in public expenditure. They argue that public expenditure is a prerequisite of economic growth. The public sector initially provides economic infrastructure such as roads, railways, water supply and sanitation. As economic growth takes place, the balance of public investment shift towards human capital development through increased spending on education, health and welfare services [17]. They assumed that the state grows like an organism making decision on behalf of the citizens, while society demand for infrastructure facilities such as education, health, electricity, transport etc, and grows faster than per capita income.

ii. Bowen's Model of Public Expenditure

[6] opined that social goods are not equally available to all voters. According to him, since social goods are consumed by all individuals in a community, each of them needs to contribute for the social goods. But as Bowen rightly pointed out, we must in the case of public goods add different individuals' curves vertically. This is so because the capacity to enjoy the social goods is different for different individuals. Since each of the individuals has different valuation of the social goods, it is expected of them to contribute different amounts. Thus, the government will produce an amount of social goods equal to the 
marginal cost of supplying that good, to be equal to the marginal utilities received by the community [48].

iii. Wagner's law of increasing public expenditure

Wagner's Law is named after the German political economist Adolph Wagner (1835-1917), who developed a "law of increasing state activity" after empirical analysis on Western Europe at the end of the 19th century. The law states that there are inherent tendencies for the activities of different layers of governments to increase both intensively and extensively. It assumes the existence of an economy and the growth of the government activities in which the government sector grows faster than the economy [17].

iv. Peacock and Wiseman Theory of Public Expenditure

In 1961, Peacock and Wiseman elicited salient shaft of light about the nature of increase in public expenditure based on their study of public expenditure in England [48]. [54] suggested that the growth in public expenditure does not occur in the same way that Wagner theorized. Peacock and Wiseman choose the political propositions instead of the organicstate where it is deemed that government like to spend money, people do not like increasing taxation and the population voting for ever-increasing social services. This theory deals with the growth of public expenditure. It emphasizes the recurrence of abnormal structures which cause sizable dumps in public expenditure and revenue. Public expenditure should not be expected to increase in a smooth and continuous manner, but in jerks or a stop like fashion to accommodate special needs, such as natural disaster, war epidemics etc [17].

\section{v. Human capital investment theory}

[5] developed the human capital investment theory in which he outlined the various interactions paths between income expenditure and human capital development. According to the theory, high income allows people invest more financial resources in the quantity of education. Money can also be used to buy better educational quality, which may affect both current educational performance and future demand for education. Moreover, low income parents might push their children towards work in the labour market in order to contribute to family finances; in the absence of sufficient money transfers from their parents, children from low income families may decide to work while studying [15], with possible negative effects on their school performance, or decide to quit education at the minimum leaving age to earn money and finance their own consumption.

\subsubsection{The Economic Impact of Education on the Individual}

Traditional human capital theory stresses the central role of education [55], [4], [59], [35] [21] [23]. The main idea is that education by an individual can be regarded as an investment in human capital. Similarly, training or medical treatment are investments in human capital. As any investment, the investment in human capital entails costs and yields future benefits, and an internal rate of return to the investment can be calculated. Costs cover direct expenditure and the opportunity cost of the student's time, notably the foregone earnings as the student is not working. The investment is expected to yield future benefits to the individual, in terms of higher productivity, which will command higher earnings, and also the quality of his or her employment as educated workers tend to have higher wages, greater employment stability, and greater upward mobility in income, relative to less-educated workers [36]. Just as with all investments, the outcome is subject to considerable uncertainty, especially at the individual level.

In addition, benefits will accrue to society at large, such as the increase in the total output of goods and services produced through the increased productivity of the individual, an increased rate of productivity growth in the economy, and additional benefits to society such as more informed and socially-involved citizens and in better health. Building on traditional human capital theory, [9] developed a perspective to assess education policies over the life cycle of an individual. An investment in education matters in so far as skills are successfully acquired. In a nutshell, skills acquired over the life cycle are complementary, with two important features. The first one can be best summarised by Heckman's words: "skills beget skills". This is because already acquired skills are an input to the acquisition of further skills. The second feature is that the acquisition of skills is more productive when skills were acquired earlier on. These features result in a "skill multiplier", by which an investment in education at one stage raises the skills attained at that stage but, also, the productivity of the transformation of future educational investments into skills.

If education at secondary level is of insufficient quality, then the productivity with which investments in education at tertiary level are translated into valuable skills will be negatively affected. Investments in secondary level education in turn are more productive if the young have acquired earlier skills, in primary, pre-primary education institutions and, of course, in the home. In the context of the efficiency of public expenditure, earlier public interventions are key to make investments in tertiary education productive. A productive tertiary education system requires sound learning foundations acquired by students at earlier stages, unless it relies on attracting talented students (and faculty) from abroad. Empirical analysis, mostly for the United States, shows that education is indeed such a life-cycle process. There is also European evidence supporting this view, although far less developed [66].

There is abundant empirical literature on the private returns to education; however there are very few crosscountry comparative studies. [7] surveyed literature and found a very robust positive association between education and individual earnings in the labour market. Economic literature also considers signalling and screening models to explain the link between education and productivity. It stresses the role that education plays to signal the productivity of the individual, which is seen as an innate ability. In contrast, human capital models stress the role of education in raising individuals' productivity, which is rewarded in the labour market by higher earnings [7]. There are some challenges in the estimation of returns because education may, at least partly, reflect a pre-existing ability. 
Thus the earnings differential does not only reflect the skills acquired via educational attainment, but would also result from the way employers use educational attainment to screen for ability. Furthermore, there are many technical issues surrounding the estimation of the return to schooling, especially related to the measurement of human capital.

Despite this inherent difficulty, most studies support the human capital explanation [66]. In particular, [61] provide evidence that education is productivity-enhancing rather than a mere device used by individuals to signal their level of ability to their employer. [12], [13] also confirm causation from education to productivity. Most studies on rates of return to schooling do not explicitly distinguish between primary, secondary and tertiary education. Furthermore, returns to education can vary across the population and the marginal return to schooling is a decreasing function of schooling [7].

\subsection{Empirical Literature Review}

[34] found a negative and significant relationship between per pupil expenditures and the primary gross enrolment rate, and a positive and significant impact of total education expenditure as a proportion of GNP. Findings from the McMahon study also suggest that increasing primary education expenditures has a positive and significant impact on the primary gross enrolment rate. [51] examined the profile of educational expenditure in Nigeria from 19771998. An education expenditure model was constructed and tested using the ordinary least squares (OLS) technique. It was discovered that federal government revenue was the singular significant determinant of educational expenditure.

[16] measured the efficiency of public spending in Malta by applying two alternative non-parametric techniques: the Full Disposal Hull (FDH) and the Data Envelopment Analysis (DEA). Using a cross-country analysis of EU Member States, they estimated the efficiency scores of three output indicators each for expenditure on education and health. The findings show that whereas public expenditure in Malta appears relatively efficient at the primary and secondary levels of schooling, it is less so at the tertiary level. Concerning health, their results showed that even in the context of poor outcomes for the remaining member states, the efficiency of public healthcare expenditure in Malta is weak. [20] used ordinary least square and two stages least squares regression on a cross section of data from 50 developing and transitional economies. Their findings indicate that greater public spending on primary and secondary education has a positive impact on widely used measures of education attainment such as gross enrolment in primary and secondary education, gross enrolment in secondary education and persistence through grade four. Regression estimates showed that performance in the education sector is also affected by other factors such as per capita income, urbanization and adult illiteracy, access to safe sanitation and water, and immunization. This agrees with the findings of [37].

[30] used Stochastic Frontier Analysis (SFA) to estimate health and education efficiency frontiers for a sample of 76 countries for the period 1990-98. The study utilised primary enrolment rate as the output variable and real GDP per capita, adult illiteracy, and education expenditure per capita (private and public) as input variables. The findings suggest that neither education expenditure nor regional differences have a statistically significant impact on net primary enrolment. [47], in a study of five African countries, sort to establish whether education outcome is affected by the composition of public education spending. The study reported that enrolment rates are significantly affected by the composition of public education spending. [10] assessed the school inputs, household substitution and test scores. Employing fixed effect regression models in their analysis, evidence from India and Zambia shows that student test scores are higher when schools receive unanticipated grants, but there is no impact of grants that are anticipated. They further show that the most likely mechanism for this result is that households offset their own spending in response to anticipated grants.

[65] carried out an empirical investigation of states social spending and social outcomes with specific emphasis on education in Nigeria. The study employed panel data from 36 states of the federation. The panel data spanned from 2009 through 2013. The study applied fixed effects and random effects models. Each of the education outcomes were modelled against states spending on education and controlled for states spending on health and states per capita expenditure. Their results show that states spending on education have a significant impact on total primary enrolment, total secondary enrolment and adult literacy enrolment in Nigeria using fixed and random effects but significant using only fixed effect on total tertiary enrolment in Nigeria.

[1] assessed the significance of public expenditure management for primary education outcomes in public schools in two South African provinces (Gauteng and North West). Using cross-sectional data from 175 public primary schools and 13 local education offices, the linear OLS regression analysis finds that while misappropriation of education funds (leakages) is not strongly associated with poor education outcomes, delays on the part of the government in disbursing funds to schools are correlated with Grade 5 dropout rates. The study finds no evidence that public expenditure and total resource wealth (including public and private contributions) are significantly associated with education outcomes. [43] focused on the impact of education expenditure on economic growth as a means of achieving the desired socio-economic change needed in Nigeria. They employed time series data from 1981 to 2012. The Johansen's co-integration analysis and ordinary least square (OLS) econometric techniques were used to analyze the relationship between gross domestic product (GDP) and recurrent education expenditure and their findings indicate that though a positive relationship subsists between education expenditure and economic growth, but a long run relationship does not exist over the period under study.

[48] used vector error correction mechanism (VECM) to 
investigate the impact of government expenditure on total school enrolment and under-5 mortality rate in Nigeria in the period 1980-2010. The results suggest that government health expenditure significantly reduces under-5 mortality rate while government expenditure on education did not significantly affects total school enrolment. [64] investigated the impact of public expenditure on tertiary education and economic growth in Nigeria using time series data for the period 1990 - 2011. They employed cointegration and error correction technique and the study revealed that public expenditure on tertiary education has positive impact on economic growth in Nigeria.

[39] focused on the effect of government education expenditure and economic growth in Mozambique using quarterly data. The Johansen cointegration technique was used to examine the long run relationship among the variables while the error correction was applied to evaluate the short run adjustment dynamics. The study found out that government expenditure on education in Mozambique was quite low with a weak effect. [28] studied the effects of school spending on educational and economic outcomes. Event-study and instrumental variable models reveal that a 10 percent increase in per-pupil spending each year for all twelve years of public school leads to 0.27 more completed years of education, 7.25 percent higher wages, and a 3.67 percentage-point reduction in the annual incidence of adult poverty; effects are much more pronounced for children from low-income families. Exogenous spending increases were associated with sizable improvements in measured school quality, including reductions in student-to-teacher ratios, increases in teacher salaries, and longer school years.

[44] sought to determine the implications of public expenditure on social capital for the economic growth of Nigeria. Their result indicated that social capital had insignificant positive impact on Economic growth in Nigeria within the period under review. [31] investigated the impact of government education expenditure on economic growth in China taking into account the spatial third-party spillover effects. The results reveal that government education expenditure in China has A significant positive impact on economic growth, but expenditure in different educational level shows different results. Government education expenditure on below high-education is positive related to local economic growth, whereas the effect of education expenditure in high-education is insignificant. Also, neighboring government education expenditure shows spatial spillover effects on local economic growth and spatial spillover effects in two education level is different.

The mixed findings evident from the literature reviewed above suggest that indeed public spending and other inputs in the education system might have some inherent heterogeneity, implying that what holds in a given region or nation may not hold in another. In the light of above, this study observes that there is need to revisit how public spending on education is been allocated, in terms of the nature of impact this spending has on education outcomes in Nigeria.

\section{Methods and Procedures}

\subsection{Theoretical Framework}

This study adopts the Human capital investment theory of [5] as framework on which the empirical analysis is based. [5], in the theory, outlined the various interactions paths between income, expenditure and human capital development. High income is believed to allow people invest more financial resources in the quantity and quality of education while low income might lead to suboptimal investment in education leading to low human capital development. The aspect of this theory that is most relevant to this study is the idea that spending on education affects human capital development, as well as has potential impacts on the income earning ability of individuals. Following these explanations, this study will model education outcome against public education spending in Nigeria.

\subsection{Model Specification}

This study follows the approach of [11] and adopts the general model [20] and [22]. This model - showing the relationship between public education spending and educational outcome - is a modified education production function which is complemented with a series of control variables. Generally, an education production function describes the nexus between combinations of schooling inputs, economic and non-economic inputs and the resulting output. The production process depends, in part, on the education subsystem and its resource input but also on the noneconomic, social, economic and physical conditions. The general model used by [20] is an education production function given as:

$$
\mathrm{Y}_{\mathrm{t}}=f\left(\mathrm{X}_{1 \mathrm{t}}, \mathrm{X}_{2 \mathrm{t}}, \mathrm{Z}_{\mathrm{t}}\right)
$$

Where $Y_{t}$, is a social indicator reflecting education attainment for a country $t$, which is a function of aggregate public spending on education as a share of GDP, $X_{1 i}$; allocations to different programs within the sector; $X_{2 t}$; and a vector of socioeconomic variables $Z_{t}$.

Following the above, educational outcome is specified to depend on public educational spending as a percentage of GDP, public health spending as a percentage of GDP, GDP per capita and urbanization. Consequently, the following model is specified to examine the effect of public educational spending on schooling outcomes in Nigeria.

$$
\mathrm{PSE}=\mathrm{f}(\mathrm{PEX}, \mathrm{HEX}, \mathrm{PCI}, \mathrm{URB})
$$

Where,

PSE is Primary school enrolment rate

PEX is public educational spending as a percentage of GDP

HEX is public health spending as a percentage of GDP

PCI is GDP per capita, and

$\mathrm{URB}$ is urban population as a measure of urbanization.

Assuming a linear relationship amongst the above variables, following earlier studies (For instance, [58], [11], [65], model 2 can be re-specified in the estimable form below: 


$$
\mathrm{PSE}_{\mathrm{t}}=\alpha_{0}+\alpha_{1} \mathrm{PEX}_{\mathrm{t}}+\alpha_{2} \mathrm{HEX}_{\mathrm{t}}+\alpha_{3} \mathrm{PCI}_{\mathrm{t}}+\alpha_{3} \mathrm{URB}_{\mathrm{t}}+\mathrm{U}_{\mathrm{t}}
$$

Where $t$ represent the time periods over them which data is collected for the country, and U represent the error term.

\subsection{Justification of Variables of the Model}

As stated earlier, equation 2 is informed by earlier works such as [11] and [20], [22] with some modifications. The variables included in the model are those previous empirical research and theoretical knowledge suggest have significant bearing on education outcome, especially in developing nations. In the following paragraph we briefly explain how each of the explanatory variables interacts with the dependent variable.

Primary School enrolment rate is modelled as an education outcome. Some previous studies have used School completion rate, however we use enrolment rate because Nigeria lacks consistent time series data that is adequate for school completion rate. Studies such as [65] have also used this variable in their study of the effect of social spending on education outcome. Moreover, many efforts made at improving literacy in developing nations aim at encouraging and providing access to education. When such efforts are successful, the result is higher school enrolment rate. As noted, earlier empirical works provide justification for this.

The inputs modelled are Pubic education spending as a percentage of GDP, Health expenditure as a percentage of GDP, Per capita GDP and Urban population growth. The justification for including Education expenditure is quite selfevident: if government spends more on education mainly in a poor country, it is likely that more people would have access to school; it might reduce drop-out rates in school, while leading to better education outcome. This is however the case only when there is allocative efficiency in spending, free of fund misappropriation. Also, health standard is believed to have a strong connection with education standard [63]. If people are healthier, they will spend more time in school as well as do better, hence improving education outcome. Thus if higher health spending improves health standard, it could also improve education outcome. This again is dependent on whether spending is free of corrupt practices. GDP per capita measures the average income level in a nation. Of course higher GDP per capita suggests higher leaving standards in a nation, but does not imply that everyone is as well off, due to problems of inequality. Thus it is relevant to see how changes in per capita income levels influence education outcome, since there is a strong connection between the two variables. Finally, urban population growth is included in the model because it can tend to suggest how standard of living changes in a nation. Generally, it is believed that when people move from rural to urban areas they have a higher standard of living. Again since anything that changes income level could change investment in education, and education outcome, it is expedient to see how this change in location affects education outcome, since in developing countries urbanization is strongly linked to improved living standards.
This shows the theorized relationship between the modeled regressors and regressand. It also serves as a basis for evaluating our estimated model to ensure conformity with economic theory. Table 1 below shows the a priori expectations for the variables in the model earlier specified.

Table 1. A priori Expectations.

\begin{tabular}{lll}
\hline Regressand & Regressor & Relationship \\
\hline PSE & PEX & + \\
PSE & HEX & + \\
PSE & PCI & + \\
PSE & URB & + \\
\hline
\end{tabular}

Source: Authors Computations

\subsection{Data Sources}

Time series data over the period 1970 to 2013 is used for analysis in this study. All data used are obtained from the World Bank's World Development Indicators database, and the CBN Statistical Bulletin

\subsection{Method of Data Analysis}

Augmented Dickey Fuller (ADF) unit root test and Ordinary Least Square (OLS) technique are employed to estimate the model of the study. The choice of OLS is mainly because it minimizes the error sum of squares and has a number of advantages such as unbiasedness, consistency, minimum variance and efficiency. On the other hand, ADF test is applied to ensure that the time series data used in the analysis have constant mean and variance. The motivation is to hedge against spurious regression that may result from applying OLS to non-stationary time series data. Also, the ADF test addresses a shortcoming of the Dickey Fuller test its lack of consideration of autocorrelation in the error term by adding lagged difference terms, thereby correcting for serial correlation.

Furthermore, the models, before estimation, are subjected to multicolinearity test. After estimation, the models are subjected to tests of heteroskedasticity and autocorrelation described in the next section. Both tests are crucial so as to prevent either serial correlation or heteroskedasticity from biasing the standard errors on which inferential decisions are based. Evidence of either heteroskedasticity or autocorrelation in the model will warrant re-estimating the model by the Newey-West method, which produces Heteroskedastic and Autocorrelation Consistent (HAC) standard errors.

\subsection{Methods for Evaluation of Results}

An evaluation of the model consists of deciding whether the estimated co-efficient are theoretically meaningful and statistically satisfactory. For this study there is need for all results to satisfy both statistical criteria (first order test) and econometric criteria (Second order test). 


\section{Data Analyses and Presentation of Findings}

We begin with the result of the Stationarity tests, since empirical analysis based on time series data would be biased if the underlying data are nonstationary. As noted earlier, the test used for observing the stationarity of the time series data used for analysis in this study is the Augmented DickeyFuller (ADF) test. The results are summarized in table 2 below.

Table 2. Summary of Stationarity Tests.

\begin{tabular}{llllll}
\hline Variable & ADF statistic & Level of Sig & Lagged diff & Critical Values \\
\hline PEX & -7.454 & $1 \%$ & 3 & -3.648 \\
HEX & -3.586 & $5 \%$ & 1 & -2.955 \\
PSE & -3.120 & $5 \%$ & 1 & -2.955 & 0 \\
PCI & -5.726 & $1 \%$ & 1 & -3.628 & 1 \\
URB & -4.530 & $1 \%$ & 1 & -3.641 \\
\hline
\end{tabular}

Source: Authors Computations

Before conducting the ADF tests summarized in the table above, tests for determining the number of lags to be included in the ADF test were carried out. The selection order criteria used for these tests are the Akaike Information Criteria (AIC) and the Schwarz-Bayesian Information Criteria (SBIC). The appropriate lags suggested by these tests are reported for each variable in the fourth column of table 2. The importance of choosing an optimal lag for the ADF test is to prevent the test result from being biased by correlation of the residuals.

As seen in the table 2, public education expenditure (PEX) and Per capita income (PCI) are both stationary at level. The implication is that for the subsequent analysis, these variables would not be differenced. All the other variables in the models of the study are not stationary at level, as can be seen from the table. However, after first differencing these variables become stationary. Aside, Public Health expenditure (HEX) and Primary School enrolment (PSE) which are stationary after first differencing at 5 per cent level of significance, all other variables are stationary at the 1 per cent level of significance. Following this result, all the variables would be applied in the model at their stationary orders, i.e., first differenced stationary variables would be introduced into the model after first differencing, while level stationary variables would be introduced into the model without differencing.

\subsection{Estimated Model}

The model of the study is estimated in line with the OLS method. Before the estimation, we tested for multicolinearity in the model, since in the presence of multicolinearity, OLS estimates tend to be biased. This study relied on pairwise correlation analysis of the respective variables in the model to judge the presence or otherwise of multicolinearity in the models. The summary of the multicolinearity tests is presented in table 3 .

Table 3. Multicolinearity test.

\begin{tabular}{llllc}
\hline & D. PSE & PEX & D. HEX & PCI \\
\hline Pse D1. & 1.0000 & & & \\
Pex & 0.2577 & 1.0000 & & \\
Hex D1 & -0.1492 & -0.6099 & 1.0000 & 1.0000 \\
Pci & -0.2003 & -0.1972 & 0.0532 & -0.0446 \\
Urb D1. & 0.0943 & 0.3356 & -0.2722 & 1.0000 \\
\hline
\end{tabular}

Source: Researcher's compilation using stata output

Evident in the above tables is that none of the correlation coefficients are beyond 0.61 . Usually, concerns of multicolinearity arise when the correlation amongst regressors are up to around 0.7 . We do not observe such high correlation in our model. Thus we can proceed to fit the specified models using OLS.

Table 4. Estimated Model.

\begin{tabular}{ll}
\hline Variables & Dependent Variable: Primary School Enrolment \\
\hline Public Education spending & $1.111^{*}(0.0627)$ \\
Health expenditure & $0.153(0.932)$ \\
Per capita income & $-0.0741(0.598)$ \\
Urban Population growth & $0.157(0.935)$ \\
Constant & $-1.052(0.430)$ \\
Observations & 43 \\
R-squared & 0.497 \\
F-statisitc & $2.112(0.0983)^{*}$ \\
Durbin Watson Statistic & 1.87 \\
Heteroskedasticity test & $2.14(0.142)$ \\
\hline
\end{tabular}

Note: Robust $\mathrm{p}$-values in parentheses ${ }^{* * *} \mathrm{p}<0.01,{ }^{* *} \mathrm{p}<0.05,{ }^{*} \mathrm{p}<0.1$

Source: Regression Output 
As can be seen from the table 4, the model of the study has coefficient of determination with value 0.497 . This indicates that the fitted model explains about 49.7 per cent of the variation in primary school enrolment rate in Nigeria. This value, although not very high does not suggest our model is either bad or good. The reason is because when the purpose of modeling is to determine causal effect, the size of the $\mathrm{R}^{2}$ tends not to matter so much. We would have been concerned with the value of the $\mathrm{R}^{2}$ had it been that the purpose of this model fitting is for forecast or prediction.

More so, the F-static has a value of 2.112 and a p-value of 0.09 , suggesting that the F-static is significant at 10 percent significance level. This suggests that the modeled regressors collectively have significant impact on the primary school enrolment rate in Nigeria. Also, the test for autocorrelation and heteroskedasticity for this model indicates that inferences based on this model are reliable. The Durbin Watson static has value 1.87 , which is approximately 2 . This, by the rule of thumb, suggests that there is no problem of autocorrelation in the model. Also, Breusch-Pagan Lagrange multiplier test for heteroskedasticity is applied to the model. The null hypothesis of this test is that the residuals have constant variance. This null hypothesis is accepted for our model, as the p-value of this test is 0.142 which is greater than $5 \%$ and $10 \%$ percent conventional level of significance. Notwithstanding this, the standard errors on which inferences of this model are based are adjusted for possible effects of heteroskedasticity. The estimated coefficients of model one met their a priori expectations, aside the coefficient of per capita income growth, which contrary to expectation is negative. This does not present much of a problem, as this coefficient is not found to be significant. All the other variables, public education expenditure, health expenditure and urbanization have positive coefficients.

\subsection{Discussion of Findings}

Government expenditure on education has significant positive effect on education outcome in Nigeria measured by primary school enrolment rate. It is well known that education is one of the drivers of economic development. The more people that enroll into primary schools, the more literate the population would be, and more possibility there is that these individuals would develop skills that would contribute to national income growth. So indeed, the relevance of education to human and economic development is unarguable. Our findings show that a crucial factor in promoting human capital development and of course education outcomes in Nigeria is public education spending. In general, public education spending in developing countries is believed to be of immense importance because of the high level of poverty that often exists in these nations. Poverty limits the opportunity of individuals from attaining good education, making government sponsored or subsidized education the only avenue through which many individuals can be educated. Nigeria is not an exception here, as a huge proportion of the Nigerian schooling population relies on the subsidized public education system to be able to afford the cost of education. This study has thus shown that this effort by the government of providing access to education to a large proportion of the populace is indeed not out of place, as higher spending is associated with higher education outcomes.

There are several channels through which the observed positive effect of government spending on education outcomes materializes in reality. One part is through new schools which are built with these funds. Many rural communities in Nigeria often contend with high teacher to student ratio. Also, in some communities few numbers of schools make it difficult for some persons residing far away from the school to attend. In this situation, when government builds more schools, which warrants that more teachers be employed, the natural outcome is that more persons who initially could not attend schools would now be able to attend. Also, student teacher ratio is expected to improve, as some students would move to the new schools that are closer to them. Overall, enrolment rates will rise and student performances are expected to rise too, since lower student to teacher ratio is believed to be associated with better student performance.

Our result shows that there are other factors that have positive effects on education outcomes in Nigeria. These include health expenditure and urban population growth. Although the effects of these variables are not significant, we can say that the signs of their coefficients are reasonable. Indeed, Health and education outcomes are related in more than one way. For instance, when government spends more on health to provide better health care, people find it easier to get good treatment for some killer diseases. The implication is that students that would have performed poorly in school due to poor health status would eventually do better as health system in the nation has improved. Also, issues like absenteeism due to poor health would reduce. Urbanization also has reasonable links with education outcomes. Often people migrate to urban areas in search of a better life. More often than not, people in urban areas have higher living standards than rural dwellers. This suggests that more people in urban areas would attend schools, and there would be better schools in urban areas. Therefore, as the population of urban dwellers rise, the outlook for education tend to increase, as more people would take advantage of the better education system in urban centres. Also more people will experience social mobility. If they were too poor to send their children to schools in the rural area, soon after migration to urban areas they would be able to afford enough to finance their children's education.

\section{Recommendations and Conclusion}

Given the above scenarios and the results discussed, the following recommendations become important and apposite: The government should spend more on education, this spending need to be targeted for the desired effects to be realized. There is the need for the government to identify the 
areas that need the most attention and direct spending in that area. For instance it is important to know whether building more schools will have more pay off than upgrading existing schools. The relevance of this appraisal also comes from the fact that the Nigerian government presently faces great financing challenges in the face of falling oil revenues. In addition, the monitoring of spending is also very important; this is of great relevance, given the history of corruption and embezzlement of public funds in Nigeria. It is not enough for the government to appropriate funds for certain purposes. It is important that efforts are committed to monitoring the spending to ensure that public officials do not divert appropriated funds for private gain. If this is not done, there will continue to be leakages in the system, and desired effects of government spending on education outcome and would not be achieved. There is also need for more visible involvement of the private sector in education investment; this can be achieved if the enabling environment and necessary incentives are provided.

In conclusion, the findings of this study show that public spending on education is indeed important for better education outcomes in Nigeria. We have offered some suggestion in the foregoing which, if adhered to, has the potential of deepening the effect of government spending on education outcome for the better in Nigeria.

\section{References}

[1] Adowaa, B. (2014). Does public expenditure management matter for education outcomes? Development Southern Africa, $31(4), 535-552$.

[2] Barro, R. (1998). Human capital and growth in cross-country regressions. Technical Report Mimeo. Harvard University.

[3] Barro R. J., \& Sala-i-Martin, X. (1995). Economic Growth. New York: MacGraw-Hill.

[4] Becker, G. S. (1964). Human capital: A theoretical and empirical analysis with special reference to education. Chicago: The University of Chicago Press.

[5] Becker, G. (1975). Human capital. Chicago: Chicago University Press.

[6] Bowen, H. R. (1943). The interpretation of voting in the allocation of economic resources, the quality. Journal of Economics, 28 (1), 27-48.

[7] Card, D. (1999). The casual effect of education on earnings. In O. Ashenfelter and D. Crad (eds) Handbook of labour economics, 3, North-Holland, Amsterdam, 1801-63.

[8] Central Bank of Nigeria (2003). Annual report and statement of account, Abuja, Nigeria.

[9] Cunha, F., \& Heckman, J. (2009). The economics and psychology of inequality and human development. NBER Working Papers 14695.

[10] Das, J., Dercon, S. Habyarimana, J. Krishnan, P. Muralidharan, K. \& Sundararaman, V. (2013). School inputs, household substitution and test Scores. American Economic Journal: Applied Economics, 5 (2), 29-57.
[11] Dauda, R. (2011). Effect of public educational spending and macroeconomic uncertainty on schooling outcome: Evidence from Nigeria. Journal of Economics, Finance and Administrative Science, 16 (31), 7-21.

[12] De la Fuente, A., \& Ciccone, A. (2002). Human capital in global economy knowledge. Report to the Commission Europe, Brussels.

[13] De la Fuente, A., \& Ciccone, A. (2003). Human capital and growth in a global and knowledge-based economy. European Commission, DG for Employment and Social Affairs. Office for official publications of the European Communities, Luxembourg.

[14] De la Fuente, A. (2004). Education and growth: An overview. Institute of economic analysis. CSIC, October.

[15] Dustmann, C., \& Micklewright, J. (2001). Intra-household transfers and the part time work of children. CEPR Discussion Paper 2796.

[16] Ebejer, I., \& Ulrike, M. (2009). The efficiency of public expenditure in Malta. Economic Analysis from the European Commission's Directorate General for Economic and Financial Affairs, 6 (2)

[17] Edame, G. E., \& Eturoma, A. D. (2014). The determinants of public expenditure on educational infrastructural facilities and economic growth in Nigeria. Journal of Business Management and Economics, 5 (6), 152-161.

[18] Ferguson, R. (1991). Paying for public education: New evidence on how and why money matters. Harvard Journal on Legislation, 28, 465-98.

[19] Ferguson, R., \& Ladd, H. (1996). Additional evidence on how and why money matters: A production function analysis of Alabama Schools. In Holding schools accountable: Performance-based reform in education, ed. H. F. Ladd, 26598. Washington, DC: Brookings Institute.

[20] Gupta, S., Verhoeven, M., \& Tiongsan, E. (1999). Does Higher spending buy better results in education and health care? Washington, D. C.: International Monetary Fund.

[21] Gupta, S. \& Verhoeven. M (2001). The efficiency of government expenditure. Experiences from Africa. Journal of Policy Modelling, 23, 433-67.

[22] Gupta, S., Verhoeven, M., \& Tiongsan, E. (2002). The effectiveness of government spending on education and health care in developing and transition economics. European Journal of Political Economy, 18 (4), 717-737.

[23] Gupta, S., Schwartz, G., Tareq, S. Allen, R., Adenauer, I., Fletcher, K. \& Last, D. (2007). Fiscal management of ScaleUp aid. Washington: International Monetary Fund.

[24] Gurgand, M. (2003). Farmer education and the weather: Evidence from Taiwan (1976-1992). Journal of Development Economics, 71 (1), 51-70.

[25] Hanushek, E. (1986). The economics of schooling: Production and efficiency in publicschools. Journal of Economic Literature 24, 1141-77.

[26] Hanushek, E. (1996). School resources and student performance. In Does money matter: The link between schools, student achievement and adult success, ed. G. Burtless, 43-73. Washington, DC: Brookings Institute. 
[27] Hill, M. \& King, E. (1991). Women education in the third world: An overview. In E. M. King \& M. A. Hills (eds.) Women Education in Developing Countries: Barriers, Benefits and Policy. Washington, D. C: The World Bank.

[28] Jackson, C. K., Rucker C., \& Persico, C. (2015). The effects of school spending on educational and economic outcomes: Evidence from school finance reforms. NBER Working Paper No. 20847.

[29] James, E., King, E. \& Suryadi, A. (1996). Finance, management, and costs of public and private schools in Indonesia. Economics of Education Review, 15 (4), 387-98.

[30] Jayasuriya, R., \& Wodon, Q. (2003). Efficiency in reaching the millennium development goals. World Bank Working Paper No. 9.

[31] Jiangyi, Q. (2016). Government education expenditure, thirdparty spillover effect and economic growth in China. Journal of Sustainable Development, 9 (2), 145-152.

[32] Lindauer, D. L., \& Velenchik, A. D. (1992). Government spending in developing countries: Trends, causes and consequences. The World Bank research observer, 7 (1), 59-78.

[33] Lucas, S. (1988). The mechanics of economic development. Journal of Monetary Economics, 3-42.

[34] McMahon, W. (1999). Education and development, measuring the social benefits. New York: Oxford University Press.

[35] Mincer, J. (1958). Investment in human capital and personal income distribution. Journal of Political Economy, 66 (4), 281-302.

[36] Mincer, J. (1993). Investment in U. S. education and training. Paper presented at the International conference on Human Capital Investments and Economic Performance at Santa Barbara, November 17-19, 1993.

[37] Mingat, A., \& Tan, J. (1992). Education in Asia: A comparative study of cost and financing. Washington, D. C: World Bank.

[38] Moock, P. R., \& Jamison, D. T. (1988). Educational development in sub-Saharan Africa. Finance and Development, 25 (1), 22-24.

[39] Mussagy, I. H., \& Babatunde, M. A. (2015). Government spending on education and economic growth in Mozambique: A cointegration approach. Revista Electrónica de Investigaçãoe Desenvolvimento, 5, 1-18.

[40] Mukherjee, A. N. (2007). Public expenditure on education: A review of selected issues and Evidence. Retrieved from http://www.nipfp.org.in/working-aper/wp_2007_hd_51.pdf.

[41] Musgrave, R. \& Musgrave, P. (1989). Public finance in theory and practice (5th ed). New York: McGraw-Hill International Editions, Finance Series.

[42] Nelson, R. \& Phelps, E. (1996). Investments in humans, technological diffusion and economic growth. American Economic Review, 56, 69-75.

[43] Obi, Z. C., \& Obi, C. O. (2014). Impact of government expenditure on education: The Nigerian experience. International Journal of Business and Finance Management Research, 2, 42-48.

[44] Odo, S. I., Nwachukwu, J. O., \& Agbi P. E. (2016). Public expenditure on social capital: Implications for economic growth in Nigeria. Journal of Economics and Sustainable Development, 7 (6), 72-79.

[45] OECD/UIS (2003), Financing education - Investments and returns. Analysis of the World Education Indicators 2002 Edition.

[46] OECD/UIS (2006), Education counts: Benchmarking progress in 19 WEI Countries. World Education Indicators.

[47] Ogbu, O. \& Gallagher, M. (1991). Public expenditures and health care in Africa. Social Science and Medicine, 34 (6), 615-624.

[48] Okeke, B. C. (2014). Impact of public sector spending on health and education outcomes in Nigeria. An M. sc dissertation submitted to the department of Economics, University of Nigeria, Nsukka.

[49] Okonkwo, S. C. (2014). Perception of parents on over schooling of children at the preprimary education in Onitsha. A thesis submitted to the department of education foundations, faculty of education, university of Nigeria, Nsukka.

[50] Olayemi, S. O. (2012). Human capital investment and industrial productivity in Nigeria. International Journal of Humanities and Social Science, 2 (16), 298 - 307.

[51] Omotor, D. (2004). An analysis of federal government expenditure in the education sector of Nigeria: Implications for national development. Journal of Social Sciences, 9 (2), $105-110$.

[52] Onwioduokit E. \& Tule, M. (2002). Options for Sustainable Funding of Education in Nigeria. In Ozoesan, \& G. Evbuomwan (Eds.) Human Resources Development in Africa. Conference Proceedings of the Nigerian Economic Society (pp. 523-550). Ibadan, Nigeria.

[53] Palomba, C. A., \& Banta, T. W. (1999). Assessment essentials: Planning, implementing, and improving assessment in higher education. San Francisco: Jossey-Bass.

[54] Peacock, A. \& Wiseman, J. (1967). The growth of public expenditure in the UK. Princeton, USA: Princeton University Press.

[55] Psacharopoulos, G., \& Patrinos, H. (2004). Returns to investement in education: A further update. Retrieved from $\mathrm{http}: / /$ econpapers.repec.org/article/tafedecon/v_3a12_3ay_3a2 004 3ai 3a2 3ap 3a111-134.htm.

[56] Romer, P. (1986). Increasing returns and long run growth. Journal of Political Economy, 12-37.

[57] Romer, P. (1990). Endogeneous technical change. Journal of Political Economy, 98, S 71- S 102.

[58] Schady, N. (2002). The (Positive) effect of macroeconomic crises on the schooling and employment decisions of children in a middle-income country. Development Research Group: The World Bank.

[59] Schultz, T. W. (1971). Investment in Human Capital. New York: Free Press.

[60] Sen, A. (1999). Development as freedom. Oxford, UK: Oxford University Press.

[61] Sianesi, B., \& Van Reenen, J. (2003). The returns to Education: Macroeconomics. Retrieved from http://www1.worldbank.org/publicsector/pe/pfma07/Sianesi.p df. 
[62] Solow, R. (1956). Technical change and the aggregate production function. Review of Economics and Statistics, 39, 312-320.

[63] Todaro, M. P., \& Smith, S. C. (2009). Economic development. England: Pearson Education Limited.

[64] Torruam, J. T., Chiawa, M. A., \& Abur, C. C. (2014). Cointegration analysis of public expenditure on tertiary education and economic growth in Nigeria. CBN Journal of Applied Statistics, 5 (2), 137-146.

[65] Ude, D., \& Ekesiobi, S. (2014). Panel investigation of states social spending and social outcome: Perspective of education in Nigeria. International Journal of Economics, Finance and Management 3 (5), 244-255.

[66] Woessmann, L. (2006). Efficiency and equity of European education and training policies. CESifo Working Paper Series No. 1779.

[67] World Bank. (1980). World Development Report. Washington, D. C.: World Bank.

[68] World Development Indicators (Various Years). 